\title{
TECTONOSTRATIGRAPHIC POSITION OF THE FINNISH CALEDONIDES AT THE FENNOSCANDIAN MARGIN OF THE NORTHERN SCANDES
}

\author{
JYRKI J. LEHTOVAARA
}

\begin{abstract}
LEHTOVAARA, JYRKI J., 1989: Tectonostratigraphic position of the Finnish Caledonides at the Fennoscandian margin of the northern Scandes. Bull. Geol. Soc. Finland 61, Part 2, 189-195.

The Finnish Caledonides consist of the lower structural units characteristic of much of the northern Scandes, whose foreland is now known to be Archaean throughout its extension in Finland. The autochthonous Dividal sedimentary rocks pass very gradually into the somewhat overthrust Jerta rocks. These are capped by the Nalganas meta-arkosites, which have undergone considerable displacement. The overlying Nabar plate consists of a lower sequence of heterogeneous amphibolite - pegmatitic gneiss and an upper part of very homogeneous acidic gneiss intruded and thrust by ultramafic to mafic ophiolitic material.

The origin and tectonostratigraphic correlation of the conventional Nabar Nappe are discussed in more detail, because it has features suggesting it may be part of the overlying Seve Nappe Complex. Direct proof of this is lacking, however, and so only the special characteristics of the units are discussed and comparisons made with the adjacent Norwegian and Swedish terrains. The topmost Kalak unit, the Corrovarre Nappe, also occurs in the Finnish part of the Kalak Nappe Complex.
\end{abstract}

Key words: stratigraphy, tectonics, correlation, metamorphic rocks, nappe, Caledonides, Paleozoic, Enontekiö, Finland.

Jyrki J. Lehtovaara: Department of Geology, University of Turku, SF-20500 Tur$k u$, Finland.

\section{Introduction}

The pioneering field work of Tanner (1915) and Hausen (1942) provided a very general picture of the Finnish Caledonides as a homogeneous block of undifferentiated schists. Current views of a complex tectonostratigraphic nappe pile throughout the Scandinavian Caledonides, the Scandes, (see Gee and Sturt 1985) have only recently been applied to the Finnish area of the mountain range (Fig. 1, Lehtovaara 1986). Mapping of this area (Lehtovaara 1984) has now been practically completed.
The Scandes are commonly divided into autochthonous and allochthonous parts, and the latter further into complex nappe units (Table 1), whose tectonostratigraphy is dictated by the overthrusting history. The Finnish share is an indigenous piece of the northern Scandes on their eastern, Fennoscandian, side (Zwaan and Roberts; Ramsay et al. 1985; Stephens et al. 1985).

The present discussion of the tectonostratigraphic position of the Finnish Caledonides was triggered by new field data and some recent map complications (Gee et al. 1985; Zachrisson 1986; Krill et al. 1988; Zwaan 1988). 


\section{Tectonostratigraphy and correlation in the northern Scandes}

\section{Autochthon}

The foreland of the Finnish Caledonides is formed by the sub-Caledonian basement. Consisting of various paragneisses and mainly acidic orthogneisses (Fig. 1; Table 1), it is currently understood to be totally Archaean in age (e.g. Krill et al. 1988). Matisto (1969) previously interpreted the basement as being largely composed of Proterozoic rocks, even though he had obtained an age of about $2800 \mathrm{Ma}$ from Ropinsalmi in his Proterozoic area. Fresh Archaean evidence is now provided by a U-Pb date of $2735 \pm 51$ Ma (Idman and Eilu 1988) from a granodiorite of the foreland complex, at Palovaara some 40 $\mathrm{km}$ south of the Caledonide front. This correlates well with the older date of around $2800 \mathrm{Ma}$ in Matisto (op.cit.) and also in Skiöld (1979) from near-by Sweden. If then the slices of basement rocks found now in the lower overthrust sheets are of local provenance, they might have similar Archaean ages.

The basement is overlain by a Caledonian sedimentary cover, the shales and sandstones of very widespread »marker» strata, known as the Dividal Group (Table 1), which is recognizable over hundreds of kilometres along the Caledonian front. Its palaensedimentology and stratigraphy have now been reviewed in terms of the Finnish Caledonides (Lehtovaara 1988a) where the sedimentary sub-units are more or less contiguous even though the sequence of strata is not completely developed. Contrary to earlier observations, traces of a sub-Caledonian weathering horizon have now been found in the Finnish sector (Lehtovaara 1988b). This is further evidence for the widespread similarity in exogenic development along the extensive foreland strip of provenance of Caledonian sediment.

\section{Allochthon}

In neighbouring areas, the lowermost thrust sheet of the Caledonian nappe pile is known as

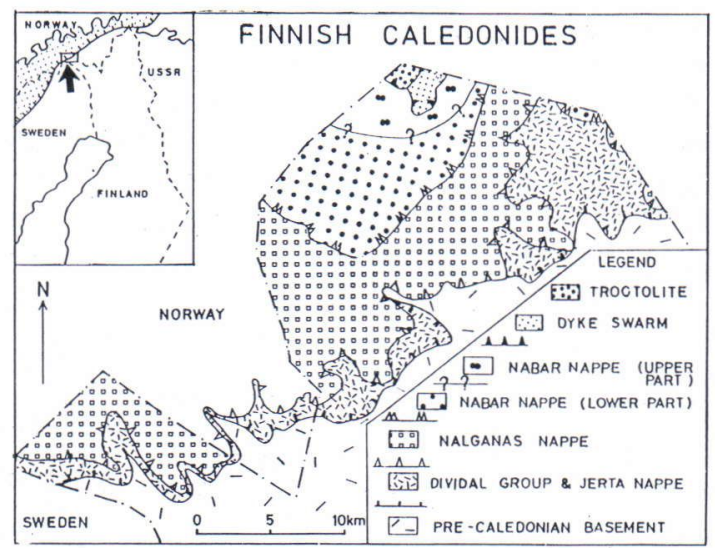

Fig. 1. Schematic map of the Finnish Caledonides showing the main tectonostratigraphic units, based on Lehtovaara (1986). The location in relation to the Scandinavian Caledonides (dotted) is shown in the key map. The overthrust surfaces are drawn with tacked lines. Troctolite $=$ Halti massif. The Dividal and Jerta units cannot be drawn separately at this scale.

the Jerta Nappe (Table 1). Here it has been displaced only a very short distance or locally not at all and, consequently, clearly shows its sedimentogenous origin (Lehtovaara 1988a). In the Alta area of northernmost Norway the corresponding rocks, there called the Bossekop Group (Zwaan 1988), have been given a Vendian sedimentation age. These sedimentogeneous rocks are thus older in parts than those of the underlying Dividal Group of Vendian to Middle Cambrian age (Ramsay et al. 1985).

The Finnish Jerta Nappe is thickened to a few hundreds of metres through tectonic imbrications (Lehtovaara 1986). It contains only a few small slices of the underlying basement, unlike the Rautas Nappe in the well known classic Torneträsk area, some $100 \mathrm{~km}$ to the southwest, where the volume of granitic basement rocks is markedly higher (Kulling 1964; Lindström et al. 1985; Kathol 1987). In accordance with the current practice of including these nappes in the next higher main unit, the Lower Allochthon, rather than in the customary Parautochthon (Gee et al. 1985; Zachrisson 1986; Krill et al. 1988), the Finnish Jerta Nappe will now be considered as 
Table 1. Current tectonostratigraphic position of the Finnish Caledonides in relation to neighbouring northern Scandes.

Main tectonostratigraphic units, originally based on Kulling (1964)
In surrounding Norway, modified from Zwaan \& Roberts (1978) and Zwaan (1988)
Recognized units in the Finnish Caledonides (this paper)
In the Torneträsk area, northern Sweden, based on Lindström et al. (1985)

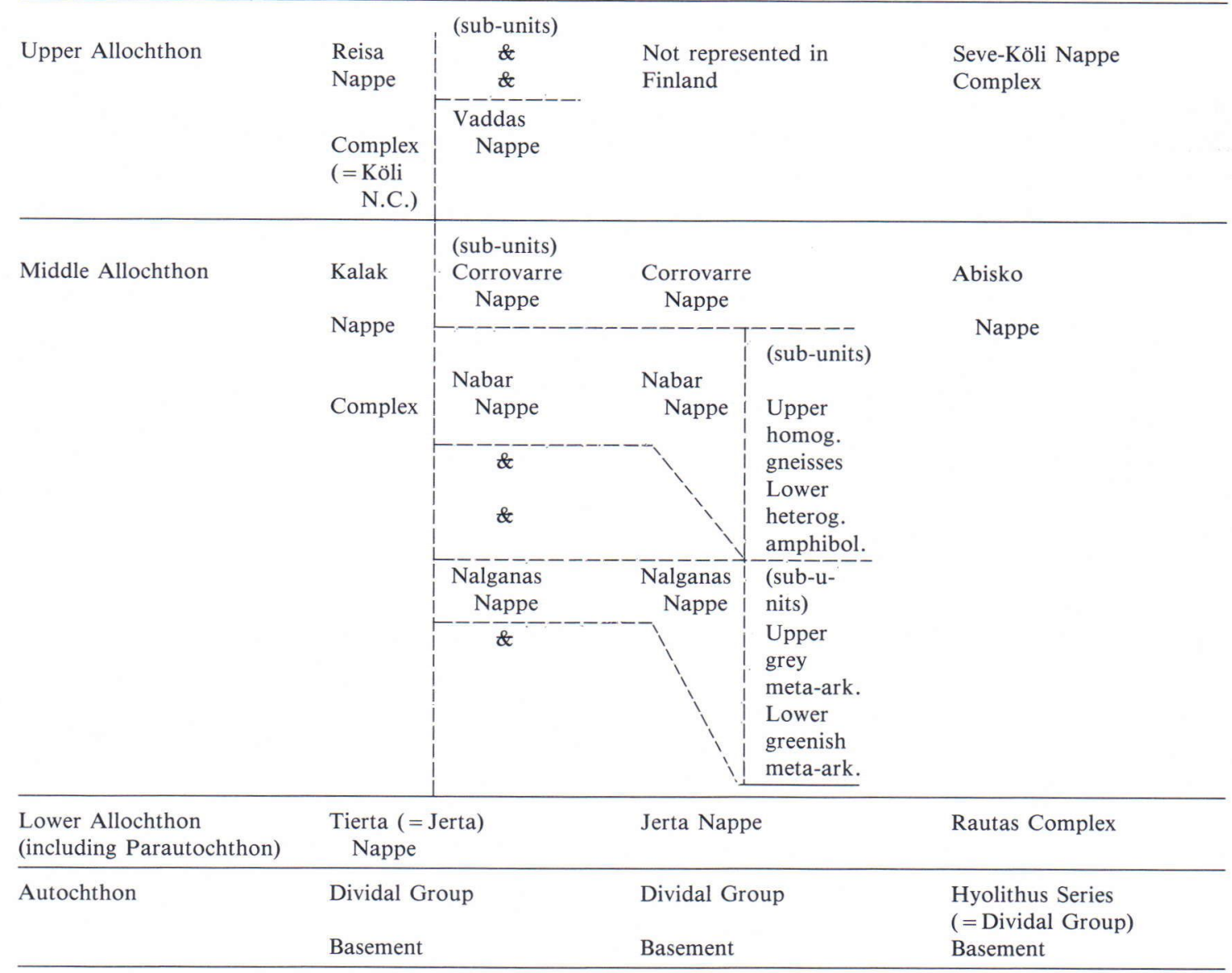

$\&=$ sub-unit existing outside the Finnish Caledonides and not included in discussion.

N.B. For the derivation of the tectonostratigraphic unit names, see Lehtovaara (1984) and (1986).

representing the Lower Allochthon (Table 1), even though a parautochthonous position is still more consistent with observed field relations.

The upper contact of the Jerta Nappe towards the much farther displaced rocks of the Middle Allochthon, now redefined as the Kalak Nappe Complex by Zwaan (1988) in the surrounding Norwegian territory, is usually very sharp (Lehtovaara 1984) although there are a few places where a gradual contact has now been recovered. This nappe complex covers the remainder of the Finnish Caledonides and it is currently considered to be of early Caledonian, Finnmarkian, emplacement, whereas the overlying nappes outside the Finnish territory are of main Caledonian, Scandian, thrust emplacement. However, the existence of a separate Finnmarkian orogenic phase has been challenged by Krill and Zwaan (1987). 
In Finland, the lowermost nappe in the Kalak Nappe Complex is the Nalganas Nappe (Table 1; Zwaan 1988). Here, as well as in Norway, the tectonic development of the Nalganas Nappe has led to a very homogeneous, thoroughly schistose succession of blastomylonitic meta-arkoses, with some epidote or local biotite or a few thin strips of chlorite-dominated rock. An analysis of a typical meta-arkose is shown in Table 2. However, the Finnish Nalganas is devoid of the granite mylonites that characterize the corresponding Abisko Nappe in the Torneträsk rocks, which are otherwise similar in many ways.

The next, and apparently topmost, unit in the Finnish Kalak Complex is the Nabar Nappe (Table 1), which covers the remaining third of the area of the Finnish Caledonides proper (Fig. 1). Decidedly the most complex unit of the Finnish tectonostratigraphy, it occupies a very extensive and lithologically heterogeneous part of the surrounding Norwegian terrain (Zwaan 1988). However, when correlated southwestwards, it seems that an upper unit of the Middle Allochthon first wedges out (Zwaan and Roberts 1978; Zwaan 1988) before disappearing altogether in the Torneträsk area (Kulling 1964; Lindström et al.
1985). There its position upon the Abisko Nappe is taken by the Seve Nappe Complex of the Upper Allochthon. Most of the maps mentioned above show that from here the Seve Nappe Complex tapers strongly towards the northeast. After the Pältsa area of the northernmost tip of Sweden, as noted by Binns (1978), the Seve can no longer be identified in the field among the Caledonide nappes. Recently, Zachrisson (1986) has published the interpretation that the upper part of the current Kalak Nappe Complex - consisting mainly of the Nabar Nappe and including the Finnish area - would be part of the Seve Nappe Complex.

In Finland, the lower contact zone of the Nabar Nappe can be distinguished by the first appearance of amphibolites (see Table 2 for analyses) in the schist succession, if not before, accompanied by an overall coarsening in grain size and the occurrence of sheared pegmatite material (Table 2). Upwards, the volume of acidic schists increases heavily.

Lying in a very inhomogeneous assemblance, a minute $\mathrm{Zn}$ mineralization hosted by graphitic and partially chloritized rocks (Table 2) was found in the course of geochemical sampling for

Table 2. Chemical analyses of some allochthonous rocks from the Finnish Caledonides. $1=$ meta-arkose, Vuobmakasjavri, 2 = amphibolite, Kovddoskaisi top, 3 = schistose acid gneiss, Pihtsosnjunni, 4 = chloritized graphitic gneiss, NE Kovddoskaisi, 5 = sillimanite-bearing gneiss, Ridnitsohkka, $6=$ anatectic granite, Ridnitsohkka, $7=$ tonalitic vein, Halti.

\begin{tabular}{|c|c|c|c|c|c|c|c|}
\hline $\begin{array}{l}\text { Sample } \\
\text { No. }\end{array}$ & 1 & 2 & 3 & 4 & 5 & 6 & 7 \\
\hline $\mathrm{SiO}_{2}$ & 89.44 & 44.20 & 78.45 & 49.24 & 53.43 & 74.37 & 72.22 \\
\hline $\mathrm{TiO}_{2}$ & 0.40 & 2.46 & 0.31 & 1.91 & 1.52 & 0.29 & 0.38 \\
\hline $\mathrm{Al}_{2} \mathrm{O}_{3}$ & 6.70 & 12.90 & 14.43 & 9.27 & 27.10 & 14.95 & 16.50 \\
\hline $\mathrm{Fe}_{2} \mathrm{O}_{3}$ & 1.75 & 15.5 & 0.64 & 11.52 & 8.50 & 2.02 & 1.91 \\
\hline $\mathrm{MnO}$ & 0.04 & 0.19 & 0.00 & 0.13 & 0.15 & 0.01 & 0.01 \\
\hline $\mathrm{MgO}$ & 0.15 & 3.87 & 0.12 & 4.98 & 1.16 & 0.11 & 0.49 \\
\hline $\mathrm{CaO}$ & 1.23 & 6.82 & 0.97 & 3.53 & 0.82 & 0.71 & 3.47 \\
\hline $\mathrm{Na}_{2} \mathrm{O}$ & 1.02 & 3.01 & 3.50 & 1.82 & 1.37 & 3.05 & 3.7 \\
\hline $\mathrm{K}_{2} \mathrm{O}$ & 1.7 & 0.20 & 3.15 & 2.40 & 2.08 & 4.6 & 1.1 \\
\hline 1.o.i. & 0.57 & 0.42 & 0.55 & 13.60 & 1.47 & 0.68 & 0.45 \\
\hline Sum & 103.00 & 103.7 & 101.57 & 98.40 & 97.70 & 100.1 & 99.8 \\
\hline
\end{tabular}

Analyses made by standard AAS and XRF techniques at Department of Geology, University of Turku, Nos 1, 5, 6, 7 by Tapio Glumoff, 2, 3, 4 by Arja Rannikko. coordinates of the samples
$17689.7 / 1272.1$
$3 \quad 7692.9 / 1272.3$
$5 \quad 7699.4 / 1276.8$
$7 \quad 7702.1 / 1273.6$
$27693.1 / 1270.3$
$47696.0 / 1270.2$
$67698.8 / 1276.8$ 
the Finnish Nordkalotten Project (A. Björklund, pers. comm.) and reported by Zachrisson (1986).

The top third of the Finnish Nabar Nappe is made up of a very monotonous sequence of thinly banded garnetiferous gneisses (Lehtovaara 1984). Any primary sedimentation structures in them have been obliterated by thrusting and metamorphism of high amphibolite grade of a protolith that is generally assumed to be metaarkositic (Zwaan and Roberts 1978).

The top of this gneiss succession has been intruded by a swarm of dykes, or rather sills, of non-ophitic fine-grained biotitic gabbro (Lehtovaara $1984 ; 1987)$ that now display an apparently concordant relationship with the country rock. Uppermost in the Finnish Caledonides and in physical continuation with these Ridnitsohkka dykes lies an ultramafic to mafic body, the Halti massif proper of Lehtovaara and Sipilä (1987). These two magmatic units together were originally proposed to form part of an ophiolite body (Lehtovaara 1984). Also shown to resemble an ophiolite in chemistry, the Halti massif may in fact have originated apart from the Ridnitsohkka dykes (Sipilä; Lehtovaara and Sipilä 1987). As there is no thrust contact found between them, it is, however, hard to consider them as separate units and they are more likely both products of the rift magmatism phase of the opening Iapetus Ocean.

Mainly on topographic grounds, Lehtovaara (1984) proposed that these magmatic bodies might belong to the next overlying nappe, then thought to be the Vaddas Nappe (Zwaan and Roberts 1978), consisting of a very heterogeneous rock assemblage (Padget 1955). However, Zwaan (1988) now considers that the Vaddas Nappe belongs to a totally different superunit, the clearly younger Scandian-emplaced Reisa Nappe Complex (Table 1). Zwaan (op.cit.) also proposed from the topmost part of the Nabar Nappe a new unit, the Corrovarre Nappe, of overwhelmingly basic magmatics, to which the corresponding Finnish basic magmatic bodies should preferably be ascribed. At present, how- ever, an unambiguous lower thrust contact (zone) for an equivalent of the Corrovarre Nappe has not been found in the Finnish area.

\section{Genetic interpretations}

On the basis of common rock units, lithological comparison and interpretation can be made between the classic tripartite Seve Nappe Complex typical of the Torneträsk area (Kulling 1964; Lindström et al. 1985; Kathol 1987) and the Finnish Nabar Nappe described above. It is not difficult to point to obvious similarities on the Finnish side: a biotite-characterized phyllonitic schist zone is found in many places in what is now the topmost part of the Nalganas Nappe; in the middle, a thick heterogeneous succession is characterized by amphibolites and gneissified rocks; and the top is made up of a section of homogeneous gneisses covered by basic bodies. The corresponding divisions of the Torneträsk Seve are very similar.

In the Norwegian studies (Ramsay et al. 1985), the amphibolitic middle unit of the Nabar Nappe has been interpreted as consisting of early Proterozoic, even Archaean, basement rocks. This concept does not support the existence of Seve material, which should typically consist of much younger sedimentogeneous and volcanogeneous rocks of Baltoscandian margin origin. Instead, $\mathrm{Pb}-\mathrm{Pb}$ isotope data (Sundblad, in press) on the $\mathrm{Zn}$ mineralization mentioned above do not, in my opinion, really contradict the "Seve» derivation, especially as Sundblad (Pers.comm.) thinks that sthe lead isotopic composition of galena in the small sulphide mineralization indicates that the metals were derived from Early Proterozoic upper crustal units with Baltoscandian affinity».

In conclusion, there do not seem to be, at present, any tangible facts to support arguments for the presence of the Seve Nappe or its equivalent in the Finnish Caledonides or areas northeast of them. However, the absence of the Seve from the northern Scandes is an exception to the high regularity of the nappe structure of the Scandina- 
vian Caledonides. Thus fresh studies are called for, especially in view of the presence of the next higher unit, the Köli Nappe Complex, in some of these areas. The ongoing radiometric dating of the neighbourhood in Sweden and also in the Finnish Caledonides may well yield some useful dates, but the record of existing Caledonide age determinations shows that, owing to the very complex geological histories of the rocks, the dates should be interpreted with care.

On the other hand, there are now ample observations to show that the upper third of the Finnish Nabar Nappe has been under higher pT conditions than the underlying units. An increase in metamorphic grade from the underlying units, although characteristic of the Seve Nappe, is not sufficient proof of its presence. The proven Seve dyke swarms cut their psammitic country rocks, e.g. the Juron quartzites of the Sarek area (Andréasson 1986) or the Vaivvančohkka sandstone-siltstone formation of the Torneträsk area (Kathol 1987). There the bedding and other primary structures are cut by the dykes, whereas the Ridnitsohkka dykes are concordant with their country rock. The present concordancy could be due, however, to metamorphic recrystallization at the gneisses (analysis given in Table 2). These rocks, which are of high grade and contain sillimanite and kyanite, are not strongly foliated and any primary sedimentation structures are not preseved. Apart from also existing in the amphibole rock of the Halti massif proper (Lehtovaara and Sipilä 1987), kyanite further occasionally occurs down to the bottom contact of this homogeneous gneiss unit.

Finally, the existence of small volumes of migmatite forming granitic material (analysed in Table 2), not far beneath the dyke swarm (Lehtovaara 1986), and of thin tonalitic veins (Table 2)

\section{References}

Andréasson, P.-G., 1986. The Sarektjåkka Nappe, Seve terranes of the northern Swedish Caledonides. Geol. För. Stockholm Förh. 108, 263-266. cutting the Halti massif (Lehtovaara 1984) are, in my opinion, proof that the rocks reached their melting conditions locally; at what particular time that occurred has still not been dated, though.

The extent of near-melting, and locally melting, conditions may have been relatively limited, but approximately similar pT conditions should have been reached beyond the Finnish area somewhere in the tectonostratigraphically equivalent sequences. A promising candidate is the lithologically similar-looking Bäggegähaldi area (Zwaan 1988), some $35 \mathrm{~km}$ northeast of the Finnish border.

Although there is no field evidence, an explanation for the increased pT values could be that the highest unit of the Nabar Nappe represents a tectonic fragment of a deeper crust. However, it is not impossible that Caledonian subduction caused a deeper incursion into the crust at some earlier phase of the thrusting of this nappe unit. In that case, the nappe might be correlated to the Seve Nappes, which would then begin from the highest division of the Nabar Nappe upwards.

A more probable, and simpler, explanation for the pT increase, as first proposed by Lehtovaara (1986), is that at the early rifting stage the volume of hot intruding ultramafic to mafic magmas was so great that the local temperatures remained high enough for metamorphic reactions and incipient melting to occur.

Acknowledgements. This paper is a contribution to IGCP Project 233 »Terranes in the Circum-Atlantic Paleozoic Orogens». - My thanks are due to K.B. Zwaan of NGU, Trondheim, and to two anonymous referees of this Bulletin for constructive comments on the original manuscript, to Tapio Glumoff and Arja Rannikko, University of Turku, for making the analyses, and to the Academy of Finland for financial support.

Binns, R.E., 1978. Caledonian nappe correlation and orogenic history in Scandinavia north of lat. $67^{\circ} \mathrm{N}$. Geol. Soc. Amer., Bull. 89, 1475-1490.

Gee, D.G. \& Sturt, B.A., 1985. The Caledonide Orogen Scandinavia and Related Areas. John Wiley \& Sons, 
Chichester.

-; Kumpulainen, R.; Roberts, D.; Stephens, M.B.; Thon, A. \& Zachrisson, E., 1985. Scandinavian Caledonides Tectonostratigraphic Map. Sver. Geol. Unders. Ser. Ba Nr. 35.

Hausen, H., 1942. Der Abschnitt Finnlands der kaledonischen Überschiebungszone. Soc. Sci. Fennica, Com. Phys.Math. 11, 9, 117 p.

Idman, H. \& Eilu, P., 1988. Granitoidien muuttuminen varhaisproterotsooisen vihreäkivikompleksin länsireunalla Enontekiöllä - esimerkki kemiallisesta rapautumisesta. (In Finnish). Ann. Univ. Turkuensis, Ser. C, Tom. 67, 39-52.

Kathol, B., 1987. The Váivvančohkka Nappe, Torneträsk area, northern Swedish Caledonides. Geol. För. Stockholm Förh. 109, 350-353.

Krill, A.; Kesola, R.; Sjöstrand, T. \& Stephens, M.B., 1988. Metamorphic, Structural and Isotopic Age Map, Northern Fennoscandia, 1:1 mill. Geol. Surv's Finland, Norway and Sweden, Helsinki 1988.

— \& Zwaan, B., 1987. Reinterpretation of Finnmarkian deformation on western Sørøy, northern Norway. Norsk Geol. Tids. 67, 3-13.

Kulling, O., 1964. Översikt över norra norrbottensfjällens Sver. Geol. Unders. Ba 19, 166 p.

Lehtovaara, J.J., 1984. Suomen kaledonidien rakenteesta. Summary: Features of the structure of the Finnish Caledonides in the northwesternmost Finnish Lapland. Geologi 36, 1-9.

-, 1986. Tectonostratigraphical outline of the Finnish Caledonides. Geol. För. Stockholm Förh. 108, 291-294.

—, 1987. Enontekiön Ridnitsohkkan emäksinen juoniparvi. Abstract: Basic dyke swarm at Ridnitsohkka fell in northwesternmost Enontekiö. Geol. Surv. Finland, Rep. Invest. 76, 199-203.

-, 1988a. The palaeosedimentology of the autochthon of the Finnish Caledonides. Geol. Surv. Finland, Spec. Paper 5, 255-264.

-, 1988b. Pre-Caledonian weathering as revealed by the Caledonian basal conglomerate at Kilpisjärvi-Halti, NW Finland. Preglacial Weathering and Landform Evolution in Fennoscandia, Symposium Abstracts, May 16-20 1988, Hörby, southern Sweden.

— \& Sipilä, P., 1987. Revisions to tectonostratigraphy and magmatism of the Finnish Caledonides. Geol. För. Stockholm Förh. 109, 354-357.
Lindström, M.; Bax, G.; Dinger, M.; Dworatzek, M.; Erdtmann, W.; Fricke, A.; Kathol, B.; Klinge, H.; von Pape, H. \& Stumpf, U., 1985 Geology of a part of the Torneträsk section of the Caledonian front, northern Sweden. In Gee, D.G. \& Sturt, B.A. (eds.), The Caledonide Orogen - Scandinavia and Related Areas. John Wiley \& Sons, Chichester. pp. 507-513.

Matisto, A., 1969. Suomen Geologinen Yleiskartta. General Geological Map of Finland, Sheet B8, Enontekiö. Kivilajikartan selitys (English Summary). 78 p.

Padget, P., 1955. The geology of the Caledonides of the Birtavarre region, Troms, northern Norway. Norges Geol. Unders. 192, 107 p.

Ramsay, D.M.; Sturt, B.A.; Zwaan, K.B. \& Roberts, D., 1985. Caledonides of northern Norway. In Gee, D.G. \& Sturt, B.A., (eds.), The Caledonide Orogen - Scandinavia and Related Areas. John Wiley \& Sons, Chichester, pp. $163-184$.

Sipilä, P., 1987. Haltitunturin alueen magmakivet. Unpublished thesis, Dept. Geology, Univ. Turku, 74 p.

Skiöld, T., 1979. Zircon ages trom an Archean gneiss province in northern Sweden. Geol. För. Stockholm Förh. 101, $167-171$.

Stephens, M.B.; Gustavson, M.; Ramberg, I.B. \& Zachrisson, E., 1985. The Caledonides of central-north Scandinavia - a tectonostratigraphic overview. In Gee, D.G. \& Sturt, B.A., (eds.), The Caledonide Orogen - Scandinavia and Related Areas. John Wiley \& Sons, Chichester. pp. $135-161$.

Sundblad, K., in press. Precambrian metal sources in sulphide deposits in the northernmost part of the Scandes. Geol. För. Stockholm, Förh.

Tanner, V., 1915. Studier öfver Kvartärsystemet i Fennoskandias nordliga delar III. Bull. Comm. géol. Finlande 38, $815 \mathrm{p}$.

Zachrisson, E., 1986. Scandinavian Caledonides: Stratabound Sulphide Deposits. Sver. Geol. Unders. Ba 42.

Zwaan, K.B., 1988. Nordreisa, berggrunnsgeologisk kart M 1:250 000. Norges geol. unders.

— \& Roberts, D., 1978. Tectonostratigraphic succession in the Finnmarkian nappe sequence, north Norway. Norges geol. unders. $343,53-71$.

Received August 22, 1989

Revision accepted October 23, 1989 